\title{
City sex: views of American women and urban culture, 1869 to $1990^{1}$
}

Urban women are provocative; their mere presence has frequently stimulated observers to label the relationship between women and urban culture problematic. As Mary P. Ryan recently noted, 'To search for women in public is to subvert a longstanding tenent of the modern Western gender system, the presumption that social space is divided between the public and the private and that men claim the former while women are confined to the latter. ${ }^{2}$ What follows here is an examination of the changing discourse of the relationship between women and cities since the Civil War. Perhaps for the reason indicated by Ryan, few systematic surveys have been made of that literature. ${ }^{3}$ Only those works which explicitly posit a connection between women and urban culture are included here; it is not enough that the women described be in cities, there must be some discussion of the interaction between the two. The term 'culture' is used in the anthropological sense - culture as a way of life. Many of the works reviewed here examine women who somehow deviate from the 'ideal' woman, who in the nineteenth century seemed to be a married Protestant middle-class non-employed mother. Thus they demonstrate abundant interest in prostitutes, immigrant women and wage-earning women, as well as in politically and sexually radical women.

If it is a constant that commentators have often been distressed by the relationship between women and city life, the particular ways in which that relationship appears troublesome have changed over time. In the earliest period, from 1869 to 1920 , observers found the noticeable presence of women in places other than the home to be a problem. They sought to understand the obvious presence of women in cities by the use of theories based in morality, in biology, and in social reform. In the $1920 \mathrm{~s}$ and $1930 \mathrm{~s}$, urban historians and sociologists quarrelled with the previous perspectives and argued that the existence of diverse roles for women in cities was normal. 
Such diversity, in fact, seemed to serve as an indication that a city supported a truly urban culture. Diversity, even deviance, was to be expected since it demonstrated the existence of urban anonymity. In fact, the very acceptance of all kinds of urban women seemed to lead to a lack of interest in writing about them and little was written in the $1940 \mathrm{~s}$ and $1950 \mathrm{~s}$ on the topic.

By the 1960s, however, with the revival of feminism, the absence of women in the history of cities became the problem, and the search was on to find hidden women. Many feminist scholars hoped that the rediscovery of 'lost feminist traditions', ranging from calls for collective housework to cross-class alliances, could offer useful lessons for those interested in changing contemporary society. Since the $1960 \mathrm{~s}$ urban women's history has overlapped with the history of reform, of work, of immigration, of ethnic groups, and of sexuality, developing into a rich, diverse, complex and contentious field. Unlike much of the women's history of the last twenty years, the history of urban women has not been written as the story of women who lived their lives in a separate domestic sphere. Early attempts to describe the universal urban woman were soon supplanted by demands for recognition of the dangers in generalizing about the experiences of women who were divided by class, race and ethnicity. In the postmodern era the stories of women and urban culture arose from many voices proclaiming that history, like urban life, was heterogeneous.

\section{Problematic public women}

An 1869 tour of the hidden lives of the women of New York City titled The Women of New York; or, The Under-world of the Great City, provides a place to begin the search for city women. This book, because it is one of the first American publications to address women in cities, provides a logical place to begin this essay. Its publication, the same year that American women first won the right to vote in state elections, alerts us to a contemporary concern about women moving beyond the domestic sphere. The illustrated title page of this book suggests the variety of women's experiences in the metropolis. Directly under the words, 'The Women of New York', a demurely dressed lady arches her neck under a fringed parasol. Below this heading the page darkens with the depiction of grey tenements and the word 'Underworld'. Further down the page a coquettish woman bares both considerable cleavage and her legs. Joining her at the bottom of the page, but still in the 'underworld', an ill-clothed, pinched-faced woman of indeterminate age faces a woman attired in the habit of a religious order. Ellington promised his readers that he would expose the hidden sin and immorality, the crime, the abortions and the prostitution, of fashionable wives, beautiful daughters, and wealthy belles of New York. In addition he promised to bring to light the lives of other deviant women, 'actresses, women's rights 
champions, lady physicians and bouquet girls in the city'. ${ }^{4}$

'The author of this work,' Ellington tells his readers, 'has been thoroughly informed in regard to the subject-matter, and his purpose is to inform the public and to reform society.' He hoped that his nearly 700 pages would help the women of the Metropolis 'become as celebrated for their virtues as those of the rural districts throughout the land.' This would happen if the women of New York City would pay attention to 'the many little pleasing arts peculiar to their sex' and 'win our respect and love by their chastity, morality and good works.' City life seemed to breed women unrestrained by family ties and the behaviour of those women bothered Ellington. His very distress, however, alerts us to both a post-Civil War concern about the failure to contain women in domesticity and to the contemporary impossibility of ignoring women's diverse public roles in urban society. ${ }^{5}$

The concern about women's non-domestic activities continued after Ellington, although the approach to examining the problem altered. Twenty years after Ellington's sensational exposé, Carroll D. Wright, the United States Government Commissioner of Labor, undertook a scientific survey of the working and living conditions of female manual labourers in 343 industries in twenty-two cities. Primarily single, healthy, daughters of immigrants, living with their parents, these young women assisted their mothers with housework and helped to support their families. Although most young working girls lived with their parents, the report evidenced a concern about young women alone in the city. It counted and classified boarding homes which offered protection against the 'perilous freedom from all restraint' faced by urban women. These homes offered a wellmaintained domestic environment complete with religious services, health care and supervision. Concerned about the morality of young wage-earning women, the government conducted interviews with prostitutes. The survey concluded that domestic employment, rather than wage labour, was more closely linked to prostitution. Unlike Ellington's women, the working girls interviewed in this study remained virtuous with the aid of benevolent employers, churches and schools. The institutions of philanthropy, school, church and work had begun to assume the role of the family in the lives of urban working women, helping to prevent the problem of excessive freedom in the nation's largest cities. Rather than returning women to domesticity, as Ellington had called for, Wright suggested a need for expanding urban institutions to protect young women. ${ }^{6}$

The problem of women in cities also attracted the attention of another late nineteenth-century social scientist, Adna Ferrin Weber. The Growth of Cities in the Nineteenth Century: A Study in Statistics (1899) investigated urban life throughout the world. Like Wright, an early specialist in the use of statistics, Weber was struck by the peculiar fact that women outnumbered men in cities. He found the pattern to be most extreme among Northern immigrants and 
Southern African-Americans, in part because different patterns of migration seemed to be based on the availability of urban domestic employment for women. But he also relied on biological explanations for this sex population difference which he considered problematic. Weber referred especially to the work of Karl Bucher, a German who named the problem of disporportionate numbers of urban women Frauenuberschuss, or over-supply of women. Bucher theorized that the 'imbalance' of the sexes occurred because 'city population has of itself a tendency to produce an excess of women above the general average.' The proportion of female births, he reported, was larger in the city than in the country. The theory held that in the city there was less inbreeding than in the country, giving rise to more female births. The supposed proof of this was an excess of boy births among inbred Jewish families. Additionally, male children had been found to be more likely to suffer from infant mortality than female infants, and infant mortality was higher in the cities than the rural areas. Among adults, Weber thought, urban men were more likely to encounter violent deaths than urban women, providing yet another reason for the higher proportion of women in cities. ${ }^{7}$ For Weber, it is not the presence of women themselves which is the problem, but the 'imbalance' of male and female urban residents.

Ellington anguished over the diversity of the public lives of urban women and called for a morality campaign to return them to the role of private homemaker exercising influence as mother, sister, wife and loved one; Wright and Weber saw the female presence in cities as problems to be scientifically studied. But by the 1880 s female observers, also troubled by the urban conditions they saw, argued for domestic and urban reform, rather than a simple return of women to the home. Helen Stuart Campbell described the lives of urban women in her 1882 account of mission work in the Five Points area of New York City, The Problem of the Poor: A Record of Quiet Work in Unquiet Places. Unlike Ellington, who suggested that a return to domesticity would cure what he saw as the moral failings of urban women, Campbell did not see the home as a place of safe retreat. Low wages forced women to live with whole families crowded into a single room, to suffer from the physical and emotional abuse of alcoholic husbands and fathers and to work ceaselessly in a futile effort to earn a living wage. She suggested a need for society to improve the home lives of urban dwellers through providing every family its own home. Then, she posited, domestic culture could cure problems such as alcoholism. Cooking schools, Campbell hoped, would bring to urban women 'the knowledge of cheap and savory preparation of food' which would lead to a decline in the number of drunkards. For Campbell, it was not the simple return to the home, but the reform of the home through scientific homemaking knowledge, which would allow the home to become an agency of social reform. ${ }^{8}$

Charlotte Perkins Gilman, Campbell's friend and one of the leading intellectuals of the women's movement of her time, argued that, for 
women, urban life was preferable to rural life. She thought the mental health of urban women was better than that of rural women. 'On wide Western prairies, go anywhere in lonely farm houses,' she wrote in her 1898 book, Women and Economics, "the women of to-day, confined absolutely to this strangling cradle of the race, go mad by scores and hundreds.' In the cities, with less emphasis on home life and more excitement, amusement and variety, women had better mental health. 'What is really felt' in urban areas, Gilman suggested, was 'the larger social interests and the pressure of forces newer than those of the home circle.' In Gilman's analysis, rural women were an example of the danger of female domestic isolation where biology and environment combined to produce 'a state of morbid and excessive sex-development.' To defeat this, Gilman encouraged the entry of women into the social and economic world. That would happen most easily through a reordering of traditional domestic responsibilities and of urban and domestic space. She proposed, for example, specially designed kitchenless apartment houses for professional women with families. The domestic work for all residents of these apartments, such as cooking, cleaning, day nursery and kindergarten, would be centrally provided. Through collective organization urban women would have the privacy of their own homes, food and services, at a lower cost and with much less labour than in traditional, individual homes. ${ }^{9}$

By the end of the nineteenth century other urban women sought to domesticate city life through the creation of settlement houses, such as Hull House in Chicago and the Henry Street House in New York City. Here middle-class women reformers lived and worked together, producing pioneering studies of the conditions faced by urban women and children. ${ }^{10}$ Often their concern concentrated on the fate of young women, as in The Spirit of Youth and City Streets by Jane Addams (1909). 'Never before in civilization have such numbers of young girls been suddenly released from the protection of the home and permitted to walk unattended upon city streets and to work under alien roofs,' she wrote, 'for the first time they are being prized more for their labor power than for their innocence, their tender beauty, their ephemeral gaiety.' Rather than calling for the domestic containment of these young women, however, Addams criticized urban society for failing to provide adequately for young people. In a chapter titled 'The Wrecked Foundations of Domesticity', Addams argued that the traditional way of family life of both immigrants and Anglo-Saxons was unsuited for modern urban society. Successful urban family life demanded not a retreat from the city, but rather an alliance of the 'educational, the industrial and the recreational organizations of the modern city' to provide what the home and family had offered in the past. ${ }^{11}$

The urban reform efforts of such women as Jane Addams and Lillian Wald impressed contemporaries like Mary Beard, who chronicled the civic accomplishments of middle-class women in 
Women's Work in Municipalities, a volume in a series of National Municipal League publications. Basing her work on a survey of hundreds of organizations, Beard described the diversity of women's interests and activities in cities and towns. She divided her survey into chapters on education, public health, 'the social evil', recreation, 'the assimilation of races', housing, social service, corrections, public safety, civic improvement, and government and administration. In all these areas she described active and ambitious work by American women, concluding that 'instead of being the source of all evil, woman comes quite as near to being the source of all good'. She sought to demonstrate the 'interrelation of each particular effort with larger social problems' as well as reflect on 'the general tendencies of modern social work'. She wanted to encourage more women to become involved in social movements and she wanted men to welcome their participation. Women, Beard seemed to say, had something special to contribute to urban life, and it did not depend on participation in the formal political process. ${ }^{12}$

\section{Urban culture dictates diversity}

Many of those observers of women and the city from the 1880 s to the 1910s - Campbell, Gilman, Addams, Beard - were female reformers who worked outside the academy, but by the 1920s American universities had developed social science programmes such as that of the University of Chicago Department of Sociology. William I. Thomas explicitly undertook to understand the relationship between some women and urban culture in a book entitled The Unadjusted Girl, a monograph published as a supplement to the Journal of the American Institute of Criminal Law and Criminology in 1923. ${ }^{13}$

Although the book's title indicated that the problem Thomas was interested in was the failure of urban girls to 'adjust', from the first page Thomas makes clear his approach which began with an understanding of both individual instincts and the social environment. Rather than trying to understand what was 'wrong' with urban girls who came into conflict with society, Thomas argued that one had to begin with an understanding of social behaviour as a whole in order to 'appreciate the failure of certain individuals to conform to the usual standards.' In his definition, a moral code was a set of behaviour norms which serves to regulate the expression of the wishes of the individual. Traditionally the family and the community regulated behaviour, but under modern urban conditions these restraints were rapidly vanishing, leaving a world with 'no universally accepted body of doctrines or practices'. In modern urban society sex was not a matter of individual morality. Instead it appeared to be the 'capital' that young women utilized to achieve other goals. Thomas declared that the nineteenth-century dichotomy separating women into the categories of good and bad no longer 
worked since modern urban society brought with it an abandonment of moral absolutes. By the 1920s Thomas identified a range of sexual behaviours - 'the occasional prostitute, the charity girl, the demivirgin, the equivocal flapper' all of whom, he said, 'represent the same movement, which is a desire to realize their wishes under the changing social conditions'. In the modern city the question to be asked of women was no longer whether they adhered to old standards of morality, but how well they were able to 'realize their wishes' in this new urban culture. Thomas sought to discover the rules and mores of urban society. To him, the call for the reform of either the women themselves or the conditions of the city was beside the point. ${ }^{14}$

Like the University of Chicago's Department of Sociology, the Chicago School of Social Service Administration also studied urban life. Edith Abbott, a professor at the school, published the results of twenty-five years of its investigations in 1936. The Tenements of Chicago, 1908-1935 described the history of Chicago's tenements, their changing ethnic landscape, housing conditions and reform efforts. She praised tenement house mothers for their patience and courage in making 'their miserable flats into real homes', and for taking in boarders as well as working for wages. While lauding tenement mothers, she criticized those mothers who lived in the furnished room district. There the problems of male unemployment were compounded by 'bad management on the part of the wife', leading families to a demoralized and disorderly style of life. Furnished room life, she acknowledged, also had its attractions: 'The desire for excitement that can be found in many of the rooming-house neighborhoods, for change, anonymity, for drink and narcotics, and for easier housework, combine in influencing families to adopt this manner of life ... It involves very little responsibility and much freedom.' In this she shared with Thomas an understanding that urban culture, or subculture, produced a unique style of life that needed to be evaluated on its own merits. ${ }^{15}$ Diverse behaviour of urban women, then, was not so much a problem as a product of environment.

While Chicago academics made an industry of studying local urban life, similar projects took place in New York City. The Columbia University Council for Research in the Social Sciences, for example, asked Caroline F. Ware of Vassar to direct its study of the neighbourhood of Greenwich Village. In her 1935 book, Ware described Greenwich Village as a magnet which attracted a diverse variety of people who shared in a 'repudiation of the social standards of the communities in which they had been reared.' In her chapter on the bohemian residents of the Village, Ware claimed that these Villagers shared a toleration for unconventionality in sexual matters. By the 1930 s, Ware reported, 'promiscuity was tame and homosexuality had become the expected thing' as female newcomers easily found their way into lesbian circles. Village bohemians, who 
rejected formal organizations, gathered in informal clubs to eat, drink illegal liquor, search for sex, and discuss such topics as 'the social position of a gigolo' and 'what is sex appeal?' Heterosexual bohemians rejected the 'Romantic-bourgeois family' and sought to establish a new 'experimental' family. In practice, Ware cautioned, this meant that while women as well as men were financially responsible for the family, 'the burden of the home and children tended to fall much more heavily on the woman than on the man.' Ware concluded that 'traditional controls' had failed to operate and to 'produce a coherent social life' for Village residents who had rejected the old ways. Urban life allowed the abandonment of old cultural ways and in their place put a variety of options. For Ware, as for Thomas and Abbott, urban women were simply part of urban culture. ${ }^{16}$

While social scientists were the first to study urban communities, by the 1930s historians such as Arthur Meier Schlesinger also began to look at American cities, and with them at urban women. Schlesinger devoted a chapter of his pioneering urban history, The Rise of the City, 1878-1898, to an examination of 'The American Woman' which chronicled changes in etiquette and childrearing, diet, interior home design and domestic work, as well as in women's political rights. Schlesinger viewed increases in divorce and the growth of prostitution as innately connected to the rise in urbanization and to the growing anonymity of city life. ${ }^{17}$ Another historian of the 1930s, Carl Bridenbaugh, also concentrated much of his writing on urban women on the issue of prostitution. In his study of early American cities, Cities in the Wilderness, he wrote that as early as 1646 evidence of sexual levity began to appear in such settlements as Boston and by the end of the seventeenth century 'commercialized vice' had taken hold. Bridenbaugh assured his readers this was not a sign of moral decay, but merely a natural occurrence because 'as the village grew it merely took on the normal aspects of any urban community.' Bridenbaugh sought to establish the leading role of American cities even in the days when cities were few and small. For him, as for Schlesinger, the public presence of women in cities was no call for concern. Instead, he used the existence of prostitution as an indicator of urban lifestyle, rather than of moral decay. For these historians of the 1930 s cities were places of diverse activity and they thus expected to find women in diverse roles. ${ }^{18}$

In this era Lewis Mumford also explored the role of cities in American culture. In Culture of Cities (1938) he ranged from medieval cities to the New Deal's Greenbelt towns and charted changes in family and erotic life. Mumford was an early proponent of the idea that sexuality was not a biological constraint, but was socially constructed. As urban life passed through distinct social and economic eras, so did erotic life. The medieval urban family was not a private unit, but an economic unit including unrelated domestic as well as industrial workers; the lack of private space limited erotic 
life. By the late sixteenth century the upper classes developed a sense of privacy within the home which gave rise to a new code of sexual manners. Concurrently, the separation of the home from the workplace began to isolate women from the outside world, creating a new type of woman. Echoing Charlotte Perkins Gilman, Mumford claimed the housewife became "either a specialist in domesticity or a specialist in sex, something of a drudge, something of a courtesan, more often perhaps a little of both.' Finally, in the megalopolis - the modern city grown out of control - Mumford said that the usual excess of unmarried males helped to build up 'a whole fabric of institutions based upon the commercial exploitation of sexual interests: whore-houses, dance halls, burlesque shows and girl shows, houses of assignation and hotels that serve the casual couple.' Although Mumford took the opposite position of Weber who argued that the problem was urban women outnumbered urban men, like Weber Mumford noted the sex ratio imbalance of modern life, but that served as just another indication that the modern city had grown out of control. For Schlesinger, Bridenbaugh and Mumford the presence of women in cities, particularly the presence of prostitutes, served not as evidence of moral decline, but of urban culture. All relied on anonymity as an indicator of the urban condition, and the presence of prostitution served as an easy measure of anonymity. ${ }^{19}$

By the end of the 1930s, the decade which had inaugurated the formal study of urban history curiously also signalled the beginning of a decline in investigations of urban women. Little was written about urban women in the 1940s or the 1950s. Perhaps the orientation of the Chicago School and early urban historians which accepted women as a normal part of urban life somehow made the study of women too ordinary a topic to attract interest. If there is no problem, there may be little to say about a subject. Significantly, when Betty Friedan published her 1963 bestseller, The Feminine Mystique, ${ }^{20}$ she claimed that the American press had failed to discuss any role for women but that of suburban homemaker for the past twenty years. To Friedan, life in the suburbs meant life on the margins of society. Women's exclusion from the city, Friedan thought, symbolized female exclusion from the public worlds of work and politics. With the growth of the feminist movement in the late 1960s and early $1970 \mathrm{~s}$, however, attention once again began to focus on urban women. Much of women's history since the late 1960s has been, as Jacqueline Jones and others have pointed out, implicitly biased towards the experiences of urban women.

\section{Feminist historians search for their sex in the city}

The tide began to turn in the 1970 s when such works as that of cultural historian June Sochen undertook a feminist analysis of urban culture and women. Sochen, like many other feminist 
historians, looked to women of the past for possible models of social change. In The New Woman: Feminism in Greenwich Village, 19101920 Greenwich Village appeared to Sochen to offer residents 'individual freedom and privacy along with communal activities of intellectual appeal'. Living in the Village allowed women to move beyond suffrage to embrace feminism because they were part of a community which 'encouraged them to fulfill their individual potentialities'. 'The communal experience of the Village feminist group,' Sochen wrote, 'was a unique one in American history. Never before or since has a group of feminists lived in a community so receptive to feminist values, at the same time maintaining ties to the larger American society.' In the end, however, Sochen concludes that the very community which nurtured these new feminist ideas limited their success in reaching other women. As they became isolated from the outside world their hopes for radically restructuring society died out, only to be reborn in Sochen's own time with women's liberation and a countercultural preference for communal living rather than 'a house in the suburbs'. ${ }^{21}$

Other historians, like Sochen, prompted by the contemporary feminist movement, tried to find evidence of cross-class and crossethnic solidarity among urban women. In a 1978 book Barbara J. Berg, in The Remembered Gate: Origins of American Feminism, The Woman \& The City 1800-1860, located the origins of antebellum Northern feminism not in the abolitionist movement, but in the voluntary associations of antebellum urban women. Unlike middleclass men, Berg argues, antebellum urban women did not use benevolence as a means of social control. They were motivated, she says, by a genuine desire to aid the less fortunate of their own sex and by the need to loosen 'the bonds of an imprisoning ethos that thwarted her efforts at self-realization, denied her autonomous nature, and refuted her common humanity.' Created to counter such problems as the inequity of women's economic position and masculine brutality, these organizations treated poor women and prostitutes not as sinners, but as sisters. This nineteenth-century feminist movement, born amidst urban problems, Berg concludes, 'did not limit its perspective to any one specific right but embraced many different aspects of women's emancipation.' That early feminism, unlike the later movement for suffrage, Berg said 'stood on the threshold of recognizing that the liberation of one class of women depended upon the freedom of others. ${ }^{22}$

Another approach to the study of the links between feminism and urban culture can be found in Margaret Gibbons Wilson's 1979 book, The American Woman in Transition: The Urban Influence, 18701920. She examined the changing patterns of marriage, fertility, housework, employment and voluntary activities of urban women from 1870 to 1920 to determine 'whether urban life, in general appeared to encourage particular patterns of behavior among the female residents', and to determine the role of cities in the liberation 
of women. Concentrating on middle-class white women, she noted that the story would be different for working-class women but argued that a study of middle-class behaviour patterns and values 'yields information that extends beyond class confines and presumably reflects the dominant mores of the nation.' In those years 'the unidimensional woman whose life was expected to focus solely upon home and family,' she said, gave way to modern women who left home for paid employment, or involvement with women's organizations and clubs. They lowered their fertility with birth control and cut down their housework by utilizing new urban institutions such as restaurants, laundries, apartment houses and hotels, and prepared food and ready-made clothes. Wilson thought that certain aspects of a city environment, such as the economic base of the city, had greater impact than others, such as city size. The urban sector, she concluded, 'offered women both increased autonomy within the traditional sphere of the home and an extension of their activities into the "outside" world.' The modern woman, faced with 'an expanded number of options to choose from and now conflicts to cope with' first emerged, Wilson concluded, from the cities and towns of the late nineteenth and early twentieth centuries. ${ }^{23}$

Like Berg and Wilson, Sara Evans also wrote of the importance of urban experience for women's liberation. Evans, however, looked at the twentieth century and examined the organizing efforts of white middle-class women in Students for a Democratic Society campaigns in urban ghettos from 1963 to 1965 . An attempt to take southern civil rights style organizing to the urban north, these campaigns promoted racial integration, participatory democracy and community control. Evans claimed that most of the good organizers were women, for women had the interpersonal skills 'empathy, listening, warmth, and noncompetitiveness in personal relationships' that good organizing required. Campaigns around recreation, day care, garbage, housing, welfare and schools - issues of daily life - 'sprang from the women's sphere of home and community life'. These young women, who had their first political experiences in the southern civil rights movement, had their first major successes as organizers in urban ghettos and went on to use their experiences to create the Women's Liberation Movement. ${ }^{24}$

By the early 1980s, American female scholars aggressively claimed that women had a special connection to the city. In her introduction to a special issue of Signs devoted to 'Women and the American City' Donna E. Shalala, for example, said that 'the very word "city" is a she', in languages from Egyptian hieroglyphics to French, German and Italian. Shalala argued that 'women do have a special relationship with home - and therefore, with towns and cities.' Catharine R. Stimpson added that the 'city has both enhanced and constricted women's lives; the experience of men and women in American cities is quite significantly different; and finally, studies of such divergences and their effects are original, suggestive, and necessary. ${ }^{25}$ 
Dolores Hayden, who also contributed an article to the Signs special urban women issue, the following year expanded on her claim that there exists 'a lost feminist tradition' of attempts to reshape city life to solve the problems created by a sexual division of labour. In her book, The Grand Domestic Revolution, she declared her hope that this tradition might be a source of power for modern feminists who, like their earlier sisters, continued to feel that 'the economic exploitation of women's domestic labor by men as the most basic cause of women's inquality.' She discovered a forgotten movement for co-operative housekeeping, food preparation and childcare by women she labelled 'material feminists' during the years of the rise and decline of the industrial city (1865-1930). Dedicated to women's equality, the material feminists created organizations and institutions to collectivize women's work which seemed a real possibility in an era Hayden notes, 'of increased concentration of urban population and constant technological inventions.' The defeat of their efforts seemed to come with the emphasis on single family homeownership, which began to be heavily promoted in the 1930 s. This, Hayden says, constituted 'a decisive ideological defeat for feminists and for architects and urban planners interested in housing design.' The material feminists, Hayden wrote, 'were so sure that capitalism would lead to socialism and so convinced that dense industrial cities would become cooperative human communities that they were unprepared for the development of monopoly capitalism and suburban isolation.' The massive suburbanization which took place in the twentieth century, Hayden said, guaranteed a less than equal social role for women, since it institutionalized in space and design the norm of the private household and the nuclear family. In search of guides to the liberation of contemporary women, Hayden pointed to the six decades of work by material feminists of the past which documented a rich and useful tradition of the feminist search for socialized housework and childcare which she thought to be necessary to allow women to become truly equal members of society' ${ }^{26}$

Mary P. Ryan, like Hayden, studied the ways the changing economic system and the development of cities influenced the lives of urban women. Looking at Utica, New York, she examined the birth of the modern family in the years from 1790-1865. In the early nineteenth century a new distinction between public and private life was created, and a new type of family with the mother at the centre replaced the older patriarchal model. Both men and women, Ryan argues, played an active role in this transformation. Giving a twist to the significance of urban women's reform work, Ryan demonstrated that women used their antebellum associational work as a testing ground for the new unpatriarchal family form. By the end of the 1840s, Ryan said, 'veterans of the reform era and their progeny would withdraw into the conjugal family, the better to nurture the values that had been cradled in association.' In other words, she 
concluded, 'the association itself helped to usher in the ultimate triumph of the privatized home. ${ }^{27}$

Like Mary Ryan, Nancy Hewitt studied the organizational and reform work of urban upstate-New York women in the nineteenth century. She claimed that urban reform work, rather than the private domestic sphere, dominated the lives of the middle-class women she studied. She studied the reform efforts of three groups of Rochester women and concluded that women had more in common with men of similar social background than they might have with women from different backgrounds. Differences among women were thus as notable as alliances between them. 'Rochester women activists,' Hewitt says, 'emerged in a community where the segregation of work and home, public and private life, and men's and women's sphere was incomplete.' Challenging the historiographical tradition which said women's activism developed from an urban context, out of sexually separate spheres, and motivated by the evangelical enthusiasm of the Second Great Awakening, Hewitt countered that Rochester women began their organizational activities before the religious revivals hit Rochester and that they were as likely to use secular as spiritual justifications for their work. A significant minority of women activists, she said, 'forged their tactics and goals in agrarian rather than urban environments.' Finally she found women activists appeared to work 'in tandem with men of their own economic, social and family circles and in opposition to women and men of competing circles.' Distinctions of economic resources and political influence separated women more than any common domestic role united them. ${ }^{28}$

Suzanne Lebsock, like Ryan and Hewitt, looked at urban women's associational activities and in her attempt to define the status of urban antebellum women. She concluded the picture was complex: 'it was neither a permanent retreat into a separate sphere nor a steady march from the confines of the home to the riskier and more varied regions the nineteenth century called "the world".' In her study of Petersburg, Virginia, women she concluded that although by the midnineteenth century they were experiencing more autonomy in their personal lives, at the same time they were losing in their public lives 'both the symbols and the structure of autonomy.' Women created associations to address the problems of orphans and female poor, but, by the $1850 \mathrm{~s}$, men had taken over poor relief work. At the same time that they lost out in the public sphere, Petersburg women appeared to be gaining in the private as they experienced 'greater freedom from immediate and total dependence on particular men'. Less dependent upon marriage, more able to find employment, they only collected more property and became more active in its disposition. By the 1850s they had lost the appearance of autonomous action in the public sphere. ${ }^{29}$ Lebsock, Ryan and Hewitt challenged the earlier assumptions about the connections between women's antebellum associational work and the rise of feminism. They also called into 
question assumptions about how much gender ties united women when they remained fixed in families, ethnic groups and class positions. They threw doubt on the long-standing assumption that city air made free women.

Scholars such as Sochen, Berg, Wilson, Evans, Hayden, Ryan and Hewitt all centred their work on the study of middle-class women who generally were white, native born and Protestant; these scholars differed, however, about the extent to which experiences and identities based on gender could cross barriers of race and class. Later writers, like Ryan and Hewitt, moved past assumptions about a universal female experience and stressed the commonality between women and men of the same class and race. The significance of differences among women can be seen most clearly in the work of those historians who have studied the lives of immigrant and African-American women, an endeavour which has often also looked at working women.

An early plan for this type of scholarship was offered by Susan J. Kleinberg in a 1977 essay which also reviewed the literature on urban women. Kleinberg began with praise for Schlesinger's The Rise of the City and its attention to 'women's changing roles in urban centers', but criticized proponents of the new urban history, such as Sam Bass Warner, Blake McKelvey and Samuel P. Hayes, for failing 'to analyze the urban women's experience systematically.' However, she praised the new scholarship which utilized social science methodology and was motivated by 'a concern with the masses' and 'renewed political activism for and by women' because it revitalized interest in the study of just how urbanization and industrialization affected women's social, economic, cultural and political activities. For Kleinberg, the urban experience could be broken down into quantifiable units, scientifically measured and compared in the study of such topics as how the participation of women in the labour force varied by class, ethnicity, marital status and the economic base of a city. ${ }^{30}$

Studies of urban women done in the manner suggested by Kleinberg often examined urban working-class immigrant women. An example of this approach is the May 1978 issue of the Journal of Urban History, which was devoted entirely to the topic 'Immigrant Woman and the City'. Several of the articles challenged Oscar Handlin's thesis that immigration constituted a traumatic severing of Old World ways. Most authors argued that culture was malleable, that the immigrant could bring it to America and that immigrant culture might in turn be altered by American life. Carol Groneman, for example, suggested that mid-nineteenth century Irish working women in New York City brought with them 'distinct patterns of behavior, of work, family and leisure which continued to mold their responses and adaptations to the circumstances of their new life.' Corinne Azen Krause made a similar point, arguing that Pittsburgh's female immigrants maintained a certain amount of traditional culture while 
adjusting to an urban industrial environment. To Janice Reiff Webster, on the other hand, it seemed that Scandinavian women in late nineteenth-century Seattle easily replaced their old country ways with those of a new urban environment in a city which offered them economic and social mobility. Julia Kirk Blackwelder demonstrated the dilemmas in generalizing about urban women whose experiences and perspectives differed dramatically depending upon 'cultural attitudes, financial needs, and individual perceptions of employment opportunities. ${ }^{31}$ The theme of the differences among urban women also appears in the work of Elizabeth Ewen who stressed the role of class in separating women in Immigrant Women in the Land of Dollars: Life and Culture on the Lower East Side, 1890-1925 (1985). She found similarities as well as differences in the lives of Jewish and Italian women, whom she followed from Europe, and their American-born daughters. In addition to describing the home and work lives of immigrant women, she described as well their leisure lives - and the creation of urban mass culture. Attacking the assumption that women's lives could be characterized by domestic isolation, Ewen suggests that working-class immigrant women at the turn of the century were more actively engaged in the public world and had more power in the home than did their American-born daughters of the 1950s. Immigrant women, active in their communities through strikes, demonstrations, trade union activity, boycotts, food riots, and rent protests and demonstrations had by the early twentieth century begun to lay out a vision of society in which the freedom of women and the commitment to social responsibility were joined. They created 'an alternative view of what it might mean to be an American'. Ewen concluded that immigrant women, far from being objects of pity, might make good models for contemporary feminists. ${ }^{32}$

The need for models based on the experiences of women who were not white and middle class also struck Jacqueline Jones who criticized generalizations based on the experiences of white middleclass women. Such theories, she noted, which suggested that "work outside the home always amounted to a "liberating" experience to women regardless of their race, age, or marital status' did not apply to the history of black working women. In Labor of Love, Labor of Sorrow: Black Women, Work and the Family, from Slavery to the Present Jones traced the movement of post-Civil War black women from the rural south to urban south to urban north. Urban black women migrants, Jones argued, had limited occupational opportunities and few incentives to yield themselves up totally to the work ethic. In cities, she says, kin networks formed on rural plantations remained intact and even intensified. In the late nineteenth century, as a black middle class emerged in southern cities, middle-class black women entered social reform. Jim-crow segregation, racial violence and economic hardship motivated a move to the urban north in the years from 1900-1930, but the north proved to be an 'ambiguous kind 
of Promised Land'. In the urban north black married women were five times more likely to work outside the home as women of any other racial or ethnic group, a sign of the then limited opportunities of black men. At the same time, they faced discrimination in factory jobs and exclusion from clerical and sales work. Unlike married women, young single women were able to take advantage of new urban diversions such as restaurants, cafés, department stores and theatres. Urban single black women experienced a new phase of female independence before marriage, a social role unknown to southern rural women. Other women experienced losses, such as the working-class black women who found themselves without time or resources to participate in formal organizations and thus lost the public role which they had been able to maintain in the rural south. By the 1960s blacks, as a group, were more likely to live in urban areas than whites, but urban life for them continued to be problematic. For black women city life had yet to bring liberation. ${ }^{33}$

By the $1980 \mathrm{~s}$, however, city life seemed to be connected to a more liberated sexuality. After its introduction by Lewis Mumford in the 1930 s, the study of urban sexuality faded, to reappear as a strong theme in the literature on women and cities of the 1980s. John D'Emilio, for example, wrote in Sexual Politics, Sexual Communities that the creation of a self-conscious, cohesive gay and lesbian minority began in the twentieth century with the formation of a gay urban subculture. In general lesbian public life was less visible than that of male homosexuals, but as early as the 1920 s working-class lesbians had begun to create an urban subculture centred around bars for gay women. After the Second World War port cities and centres of war industry such as Los Angeles, New York and the San Francisco Bay area offered gay men and lesbians a chance to settle in newly developing centres. In those large cities, D'Emilio said, anonymity made homosexual and lesbian socializing easier as an urban gay subculture took shape. In the 1950 s, however, he notes, the widespread labeling of lesbians and homosexuals as moral perverts and national security risks gave local police forces across the country a free rein in harassment.' Gay and lesbian bars were targeted, and thousands of people were arrested. By the early 1960s urban newspapers were printing guides as well as exposés of gay life and urban lesbian novels proliferated, all of which D'Emilio said indicated a change in attitudes and change in social reality - 'the rapid maturation in postwar America of a stable gay world that could no longer escape detection.' The gay subculture and the gay political movement, which developed in the $1950 \mathrm{~s}$, converged in the $1960 \mathrm{~s}$ when the 1969 police harassment of Stonewall Inn, a gay bar in Greenwich Village, led to riots and the organization of the Gay Liberation Front, 'a self-proclaimed revolutionary organization in the style of the New Left. ${ }^{34}$

Like D'Emilio, Kathy Peiss studied the urban geography of sexual communities, looking primarily at immigrant working-class 
heterosexuals. In Cheap Amusements she followed turn-of-the-century young women into the public world of non-domestic recreation in New York City. 'Public halls, picnic grounds, pleasure clubs, and street corners were special spaces in which gender relations were "played out", where notions of sexuality, courtship, male power, female dependency, and autonomy were expressed and legitimated.' Young single working women were able, for a few years, to partake of the new commercialized leisure. Peiss pointed out that for women this experience 'could be a source of autonomy and pleasure as well as a cause of their continuing oppression.' She further contended that young urban working-class women, rather than copying behaviour from the elite and middle-class urban women, pioneered new manners and mores. Urban immigrant women's lives were hardly confined to private space and she suggests that the demands of turnof-the-century urban women 'for self-determined pleasure, sexuality, and autonomy' continue to be compelling. ${ }^{35}$

Sexuality is one of the aspects which Joanne J. Meyerowitz examined in her 1988 book, Women Adrift: Independent Wage Earners in Chicago, 1880-1930. She looked at the lives of those diverse single women who migrated to the city and created new urban networks - subcultures based on work or neighbourhood. Studying the changing perceptions American society and popular culture entertained of the single woman who lived apart from family in the city, she charts a change from viewing these women as problems to seeing them as unexceptional. Following diverse migrants to the city, she added to the traditional explanations for migration particular female reasons for leaving home. These included desires to escape oppressive male relatives and to escape restrictions on behaviour. Noting that others have described the distinctive family and work cultures of urban women, she pays particular attention to describing the lives of those women who lived apart from family and the new subcultures they created in the 'furnished-room districts' of the city. Here amidst new institutions like apartment houses, co-operative living, cafeterias, tea rooms, dance halls and movie theatres, these 'women adrift' helped set the patterns of modern sexuality that other women later followed. These wage-earning women who lived apart from families, she argues, 'were a vanguard in the decline of Victorian culture' as they moved from rural female worlds to a sexually integrated urban environment. She concludes by describing the broader historical context for understanding the experiences of these urban women - 'the ongoing world history of industrial capitalism, urban growth, and autonomous female migration. ${ }^{36}$

Like Meyerowitz who sought to recreate the ways in which women created new ways of living in the city, Christine Stansell also found a hidden female urban world. In City of Women: Sex and Class in New York, 1789-1860, Stansell described 'a city of women with its own economic relations and cultural forms, a female city concealed 
within the larger metropolis of New York.' Stansell acknowledges the creation of a new conception of womanhood in the early nineteenth century among women of the urban propertied classes, but claimed that does not apply to the lives of the urban poor, wage workers, domestic servants and prostitutes. While middle-class women in the years after the Revolution retreated into domesticity, urban women of the labouring classes moved from domestic production into the public world. Urban labouring women, she argues, did not experience sharp distinctions between public and private. 'It was in the urban neighborhoods, not the home,' she argued, 'that the identity of working-class wives and mothers was rooted.' The sexual culture of young women and the domestic culture of their mothers differed from that promoted by urban reforming ladies who extended sisterhood only to those labouring women who conformed to the bourgeois standards. By the $1850 \mathrm{~s}$, Stansell noted, reformers were joined by lawmakers in trying to legislate working-class families into patterns of life acceptable to the middle class as the existence of the city of women increasingly conflicted with the image of women as ladies. $^{37}$

The changing discourse about urban women has recently attracted the attention of Mary P. Ryan who, in her study of nineteenthcentury New Orleans, San Francisco and New York, offers late twentieth-century readers an urban guide, similar in some ways to George Ellington's 1869 The Women of New York. Ryan, like Ellington, demonstrated that women can be located in urban space, that they were not relegated completely to a private domestic world. Like those of Ellington, Ryan's women come from all walks of life; she includes bourgeois ladies, ethnic working-class women, black female practitioners of voodoo and women's rights activists. She finds them in many public places: in ceremonial spaces of civic festivals and parades; in geographic space; in political space and debates around prostitution; and in what she calls 'the public sphere' and the role of women activists within it. In looking for women in public, Ryan deconstructs the public/private dichotomy which fuelled much of women's history in the 1970s. ${ }^{38}$ Rather than beginning with fragmentary evidence of women's public roles, such as could be found through the study of women's wage work or women's associational activities, she begins with a study of the public sphere and looks for women within it. Not an easy task, she concedes, since American historians have not yet described the public sphere of nineteenthcentury America. Building on the work of Jurgen Habermas, who described a public sphere that developed in eighteenth-century Europe with the growth of democracy, Ryan defined the public sphere as the 'realm of our social life in which something approaching public opinion can be formed.' So Ryan set out to find not only women in the public sphere, but that sphere itself. ${ }^{39}$

Challenging the traditional urban historiography which she says often pictures the city as 'so inveterately disorderly, so ridden with 
riot, vigilantism, and political conflict, that it lacks any center of indisputable authority', Ryan offers a different perspective on urban potential. She thinks cities have the possibility of creating 'cultural exchange, social creativity, and political ingenuity.' Her post-modern, deconstructive, reading of the urban landscape, rather than causing her to recoil at the urban disorder and confusion of nineteenthcentury cities, helps her see in the city 'immense political possibility, not just problems of governance but potential for reading new meaning into the term public.' In nineteenth-century American cities, she finds the public offers the possibility of combining the common good with social diversity in a 'fluid field of cultural, social and political mobilization'. Through her search for women in public, Ryan has discovered the outlines of a dynamic public sphere and curiously optimistic future for a fragmented and contentious urban culture. ${ }^{40}$

\section{Conclusion}

Over the past 120 years commentators have moved from the demimonde to deconstruction in pursuit of urban women and their interaction with city life. The earliest works all suggested that the obvious presence of women in public served, in one way or another, as an indication of the dysfunction of society. Thus, from the $1860 \mathrm{~s}$ to the 1920s writers expressed concern about the presence of women in public social space. Then, for a brief period of time in the $1920 \mathrm{~s}$ and $1930 \mathrm{~s}$, city women - from prostitutes to proselytizers - struck social scientists and urban historians as natural participants in urban culture. No longer a problem, city women failed to attract the attention of scholars in the 1940s and 1950s. However, the resurgent feminist movement of the 1960s took up the issue of women in public with a renewed vigour. Women in the academy began to look to the lives of earlier urban women in a search for women who had made choices about who they were or wanted to become. They looked, not only at the lives of middle-class white women, but increasingly at the lives of wage-earning women and of immigrant and black women. They found a diversity of experience so wide that, today in the $1990 \mathrm{~s}$, the very term 'urban women', with its suggestion of a single unifying essence, is no longer an adequate label.

Perhaps it is this inability simply to define and categorize that has made the study of urban women and urban culture so provocative. The failure of nineteenth-century women to fit the cultural definitions created for them provoked Ellington into cautioning his readers about the ways in which city life led women astray from familial domestic pursuits. Sexually provocative New York City women, he claimed, mandated a return to rural morality. In his account, 'the city' threatened a basic framework of nineteenth-century life, the manner of categorizing appropriate male and female behaviour.

On the other hand, it is that diversity of lifestyles possible in urban 
culture that feminists from Gilman on have identified as providing the necessary, if not always sufficient, conditions for female psychological health, for choice and autonomy, and for the conscious creation of community. Particularly since the $1960 \mathrm{~s}$, the insistence upon the historical diversity of urban culture and the lives of urban women has been rooted in a refusal to label or categorize a particular standard of behaviour as appropriate for all women (or all urban dwellers). The discovery of historical urban diversity has served to legitimate contemporary diversity, individualism and choice, particularly in such areas as sexuality. In deconstructing the definitions of 'women' and 'urban culture' contemporary historians may be allowing real men and women, of the present as well as the past, to have the possibility of defining themselves, a truly provocative proposal.

\section{Andrea Tuttle Kornbluh \\ University of Cincinnati}

\section{Notes}

1 My thanks to Zane L. Miller, who first suggested I write this essay and then offered his usual perceptive suggestions for improving it, and to Judy Spraul-Schmidt.

2 Mary P. Ryan, Women in Public: Between Banners and Ballots, 1825-1880 (1990), 4.

3 Hasia R. Diner, in Women and Urban Society: A Guide to Information Sources (1979), concluded that few studies from the years before the Second World War 'stood out as noteworthy or valid' with the notable exception of the work of the University of Chicago School of Sociology (Thomas, Park, Burgess, Worth and E. Franklin Frazier); however, in the years after the Second World War she found that sociologists, demographers, political scientists and anthropologists have studied societies undergoing urbanization in Asia, Africa and Latin America. 'The literature,' she noted, 'is strikingly deficient in historical analysis.' In total, the 111-page annotated bibliography contains less than fifty references to the United States. An additional bibliography is that of Deborah Husted (Women and Urban America, 1988). Susan J. Kleinberg's review essay, 'The systematic study of urban women' appeared in Class, Sex and the Woman Worker, edited by Milton Cantor and Bruce Laurie (1977), 20-42. Several other review articles, each dealing with a handful of books, have appeared in the Journal of Urban History: June Sochen, 'Myths and realities about urban women', JUH, 8:1 (1981) 107-15; Marjorie Murphy, 'Gender relations on an urban terrain: locating women in the city', JUH, 13:2 (1987), 197-206; Julia Kirk Blackwelder, 'Working class women and urban culture', JUH, 14:4 (1988), 503-10. Writing in the Spring 1980 issue of Signs: Journal of Women in Culture and Society, 5:3, 185-211, Gerda R. Wekerle offered a review of recent literature of 'Women in the urban environment', which declared: 'We know far less about women living in the city than we do about suburban women' (p. 196).

4 George Ellington, The Women of New York: or, The Under-World of the Great City (1869), title page. Ellington was an unidentified man writing 
under a pseudonym; his publisher apparently reissued the book the following year under an altered title, The Women of New York: or Social Life in the Great City.

5 Ellington, Women of New York, 8.

6 Fourth Annual Report of the Commissioner of Labor, 1988. Working Women in Large Cities (1889), 5, 31, 76-7. The cities included Atlanta, Baltimore, Boston, Brooklyn, Buffalo, Charleston, Chicago, Cincinnati, Cleveland, Indianapolis, Louisville, Newark, New Orleans, New York, Philadelphia, Providence, Richmond, St Louis, St Paul, San Francisco, San Jose and Savannah.

7 Adna Ferrin Weber, The Growth of Cities in the Nineteenth Century: A Study in Statistics (1899; reprint edn 1967), 280, 289, 290, 299. The reprint introduction to this book calls it 'the first really sound, comprehensive, and complete contribution to urban studies by an American.' Thus, at the very beginning of urban studies, city women appear as a kind of problem.

8 'Campbell, Helen Stuart', Ross E. Paulson, Notable American Women: A Biographical Dictionary (1971), vol. 1, 280-1. The Problem of the Poor: A Record of Quiet Work in Unquiet Places (1882), 218. Among Campbell's other books are Prisoners of Poverty: Women Wage-Workers, Their Trades and Their Lives (1887; reprint edn 1970); Women Wage-Earners: Their Past, Their Present and Their Future (1893; reprint edn 1972); and Household Economics: A Course of Lectures in the School of Economics of the University of Wisconsin (1897).

9 Charlotte Perkins Gilman, Women and Economics: A Study of the Economic Relation Between Men and Women as a Factor in Social Evolution (1898; reprint edn 1966), 242-4, 267, 84 .

10 See, for example, the studies of Chicago produced by Louise deKoven Bowen: Our Most Popular Recreation Controlled by the Liquor Interests: A Study of Public Dance Halls (1911); The Department Store Girl: Based Upon Interviews with Girls (1911); The Girl Employed in Hotels and Restaurants (1912); The Road to Destruction Made Easy in Chicago (1916). The autobiographies of Lillian D. Wald are The House on Henry Street (1915) and Windows on Henry Street (1934). Those of Jane Addams are Twenty Years at Hull House (1910) and The Second Twenty Years at Hull-House (1930).

11 Jane Addams, The Spirit of Youth and the City Streets (1909), 5, 45, 47. Addams repeated many of these same themes in $A$ New Conscience and an Ancient Evil (1912), an examination of prostitution in Chicago. Those unfamiliar with urban ways - the immigrant girl, the farm girl new to the city - seemed to Addams to be most susceptible to abduction into 'white slavery'. On the other hand, among long-time urban residents, department store workers seemed most likely to enter into prostitution. These palaces of consumption awakened desires in wage-earning girls who could little afford to purchase the lifestyle they sold. For Addams the social relationships in a modern city failed to restrain behaviour and as the old types of social control broke down, new types - based in law, publicity, literature, education and religion - became necessary.

12 Mary Ritter Beard, Women's Work in Municipalities (1915), v, vii, vi. A related work by Helen Christine Bennet offered biographical sketches of women like those featured in Beard's survey. American Women in Civic Work (1915) sketches the accomplishments of leading female civic activists in such fields as water supply, street sanitation, garbage collection, milk supply, tenements, and gaols, and included the careers of Caroline Bartlett Crane, Sophie Wright, Jane Addams, Kate Barnard, 
Albion Fellows Bacon, Hannah Kent Schoff, Francis A. Kellor, Julia Tutwiler, Lucretia L. Blankenburg, Anna Howard Shaw and Ella Flagg Young. The themes that Beard first developed in Women in Municipalities continued to form an important part of her work throughout her life as she wrote history which assumed that women had always been an important presence in American culture and criticized those who claimed that the history of women had been one of exclusion.

13 William I. Thomas, The Unadjusted Girl: With Cases and Standpoint for Behavior Analysis (1925).

14 Ibid., 2, 78, 109, 230-1.

15 Edith Abbott, The Tenements of Chicago, 1908-1935 (1936), 165, 223, 337. Professor Abbott thought that her school's orientation differed from that of the sociologists. She claimed they made their observations with 'the idle curiousity of the scientist' while her investigators sought to cure social ills. Unlike the Sociology Department, the School of Social Service had a large number of female faculty and graduate students. Among those involved in the use of social statistics and social research to study housing conditions in different sections of Chicago were Grace and Edith Abbott, Sophonisba Preston Breckinridge, Julia C. Lathrop and Jane Addams.

16 Caroline F. Ware, Greenwich Village, 1920-1930: A Comment on American Civilization in the Post-War Years (1935; reprint edn 1977), 235, 253, 410, 424. The members of the Council for Research in the Social Sciences listed in the book's preface included Robert M. MacIver (Chairman), Arthur Robert Burns, Eveline M. Burns, Robert S. Lynd and Schutler C. Wallace.

17 Arthur Meier Schlesinger, The Rise of the City, 1878-1898 (1933), 156, $157,159$.

18 Carl Bridenbaugh, Cities in the Wilderness: The First Century of Urban Life in America, 1625-1742 (1938; reprint edn 1971). Bridenbaugh also mentions the growth of educational opportunities for American girls, the existence of female trades people (mainly widows), and the rise of the American lady of fashion.

19 Lewis Mumford, The Culture of Cities (1938), 41, 114, 118, 265, 256. In a slightly different way, Bessie Louise Pierce (A History of Chicago, volume I: The Beginning of a Great City, 1673-1848, 1937) argued that the activities of women were essential to urban culture. Rather than singling out prostitution, Pierce, like Mary Beard, sought to include women's experiences as part of the story of urban development. Similar attention to the role of women can be found in the work of another female early urban historian, Constance McLaughlin Green (Holyoke, Massachusetts: A Case History of the Industrial Revolution in America, 1939).

20 Betty Friedan, The Feminine Mystique (1963).

21 June Sochen, The New Woman: Feminism in Greenwich Village, 19101920 (1972). Judith Schwarz's Radical Feminists of Heterodoxy: Greenwich Village 1912-1940 (1986) is another account of the lives of Greenwich Village feminists.

22 Barbara J. Berg, The Remembered Gate: Origins of American Feminism, The Woman \& the City, 1800-1860, Urban Life in America (1978), 158, $268,270$.

23 Margaret Gibbons Wilson, The American Woman in Transition: The Urban Influence, 1870-1920 (1979), 5, 11, 151.

24 Sara Evans, Personal Politics: The Roots of Women's Liberation in the Civil Rights Movement \& the New Left (1979; reprint edn 1980), 140, 1401, 141. 
25 Donna E. Shalala, 'Foreword', in Catherine R. Stimpson, Elsa Dixler, Martha J. Nelson and Kathryn B. Yatrakis (eds), Women and the American City (1980), vii. Catherine R. Stimpson, 'Preface' to same volume, ix. The articles in the book originally appeared in Signs: Journal of Women in Culture and Society, 5:33 (1980), supplement.

26 Dolores Hayden, The Grand Domestic Revolution: A History of Feminist Designs for American Homes, Neighborhoods, and Cities (1981), 1, 3, 8, $10,8,1$.

27 Mary P. Ryan, The Cradle of the Middle Class: The Family in Oneida County, New York, 1790-1865 (1981), 240, 238.

28 Nancy A. Hewitt, Women's Activism and Social Change: Rochester, New York 1822-1872 (1984), 22. Hewitt expanded on the significance of differences among women in 'Beyond the search for sisterhood: American women's history in the 1980s', published first in Social History, 10 (1985) and reprinted in Unequal Sisters: A Multicultural Reader in Women's History, ed. Ellen Carol DuBois and Vicki L. Ruiz (1990), 1-14.

29 Suzanne Lebsock, The Free Women of Petersburg: Status and Culture in a Southern Town, 1784-1860 (1984), 235.

30 Susan J. Kleinberg, 'The systematic study of urban women', in Sex, Class and the Woman Worker, eds Milton Cantor and Bruce Laurie (1977), 2042 , 3. Caroline F. Ware, who had described the Greenwich Village feminism of the 1920 s and 1930 s, wrote of the new interest in urban women in the 'Introduction' to Class, Sex and the Woman Worker, 3-19. Many of the essays in the book are 'about' urban women, but with the exception of Miriam Cohen ('Italian-American women in New York City, 1900-1950: work and school', 120-43), no writers grapple with the connection between women and urban life.

31 Journal of Urban History, 4:3 (1978), 251, 276, 356. The articles were as follows: Carol Groneman, 'Working-class immigrant women in midnineteenth-century New York: the Irish woman's experience', 255-73; Janice Reiff Webster, 'Domestication and Americanization: Scandinavian women in Seattle, 1888-1900', 275-90; Corinne Azen Krause, 'Urbanization without breakdown: Italian, Jewish and Slavic immigrant women in Pittsburgh, 1900 to 1945 ', 291-306; Julia Kirk Blackwelder, 'Woman in the workforce: Atlanta, New Orleans, and San Antonia, 1930-1940', 33158; see also Blackwelder, Women of the Depression: Caste and Culture in San Antonio, 1929-1939 (1984).

Tamara Hareven edited the Journal of Urban History, 1:3 (1975) on 'The history of the family in American urban society', but that volume treats 'urban' merely as the location of other activities. For example in her article, 'Family time and industrial time: family and work in a planned corporation town, 1900-1924' (pp. 365-89), she dispenses with the urban issue completely: 'As a planned industrial town, Manchester did not experience the classic problems of social disorganization generally attributed to urban living ... The problems that Manchester's laborers were facing, therefore, did not derive from urban anomie, but rather from the pressures of industrial work and discipline.' 'These conditions,' she concluded, 'allow the historian to examine the role of the family in the process of industrialization without the interference of factors generally connected with the pressures of life in a large city' (pp. 368-9).

32 Elizabeth Ewen, Immigrant Women in the Land of Dollars: Life and Culture on the Lower East Side, 1890-1925 (1985), 269. See also Elizabeth Ewen, 'City lights: immigrant women and the rise of the movies', in Women and the American City, 42-62.

33 Jacqueline Jones, Labor of Love, Labor of Sorrow: Black Women, Work 
and the Family, From Slavery to the Present (1985; reprint edn 1986).

Dolores E. Janiewski traced black and white women from the fields of North Carolina to the tobacco factories of Durham. Women's condition improved in the city, as they moved from unpaid work to wage labour, from rural isolation into the public realm of work, church, community and politics. They steadily gained greater freedom in the city. But while black and white women shared certain experiences, their membership in different racial communities proved difficult to transcend. See Janiewski, Sisterhood Denied: Race, Gender, and Class in a New South Community (1985).

In another account of the lives of urban black women, Elizabeth Hafkin Pleck argued that city life adversely affected black families. 'The northern city,' she claimed, 'added new temptations and eroded old beliefs and ways of living.' Rather than opportunity, city life frequently brought with it poverty, created by discrimination in employment, which placed extreme pressures on family life. Elizabeth Hafkin Pleck, Black Migration and Poverty: Boston 1865-1900 (1979), 162, 176.

34 John D'Emilio, Sexual Politics, Sexual Communities: The Making of a Homosexual Minority in the United States, 1940-1970 (1983), 139, 233.

35 Kathy Peiss, Cheap Amusements: Working Women and Leisure in Turnof-the-Century New York (1986), 6, 4, 188.

36 Joanne J. Meyerowitz, Women Adrift: Independent Wage Earners in Chicago, 1880-1930 (1988), xxiii, 142. See also Joanne J. Meyerowitz, 'Women and migration: autonomous female migrants to Chicago, 18801930', Journal of Urban History, $13: 2$ (1987), 147-68.

37 Christine Stansell, City of Women: Sex and Class in New York, 17891860 (1986), xi, 41.

38 For more on deconstruction in general see Terry Eagleton, Literary Theory: An Introduction (1983), especially 132-3.

39 Mary P. Ryan, Women in Public; Between Banners and Ballots, 18251880 (1990).

40 Ibid., 176, 175. 